\title{
HOLOCENTRUSS SOGO.
}

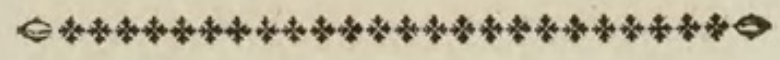

CHARACTER GENERICUS.

Opercula squamata, serrata, aculeata.

Bloch. ichth. 7. p. $4 \%$.

Thoracisi.

CHARACTER SPECIFICUS, EंC.

HOLOCENTRUS ruber, lineis longitudinalibus flavis, cauda furcata.

HOLOCENTRUS SOGO. H. pinna ventrali radiis octo.

Bloch. ichth. 7. p. 46. t. 232.

\section{HOLOCENTRUS.}

Seb. mus. 3. p. 73. t. 27 . f. 1 .

Perca marina rubra.

Catesb. Carol. 2. t. 3. f. 2 。

In maribus Indicis innascitur Holocentrus Sogo, magnitudine Percam vulgarem sive fluviatilem referens. Viro celeberrimo Carolo Plumier figuram archetypam hujus piscis debemus, a Blochio primum evulgatam. 


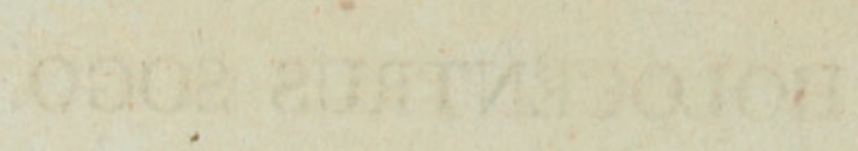





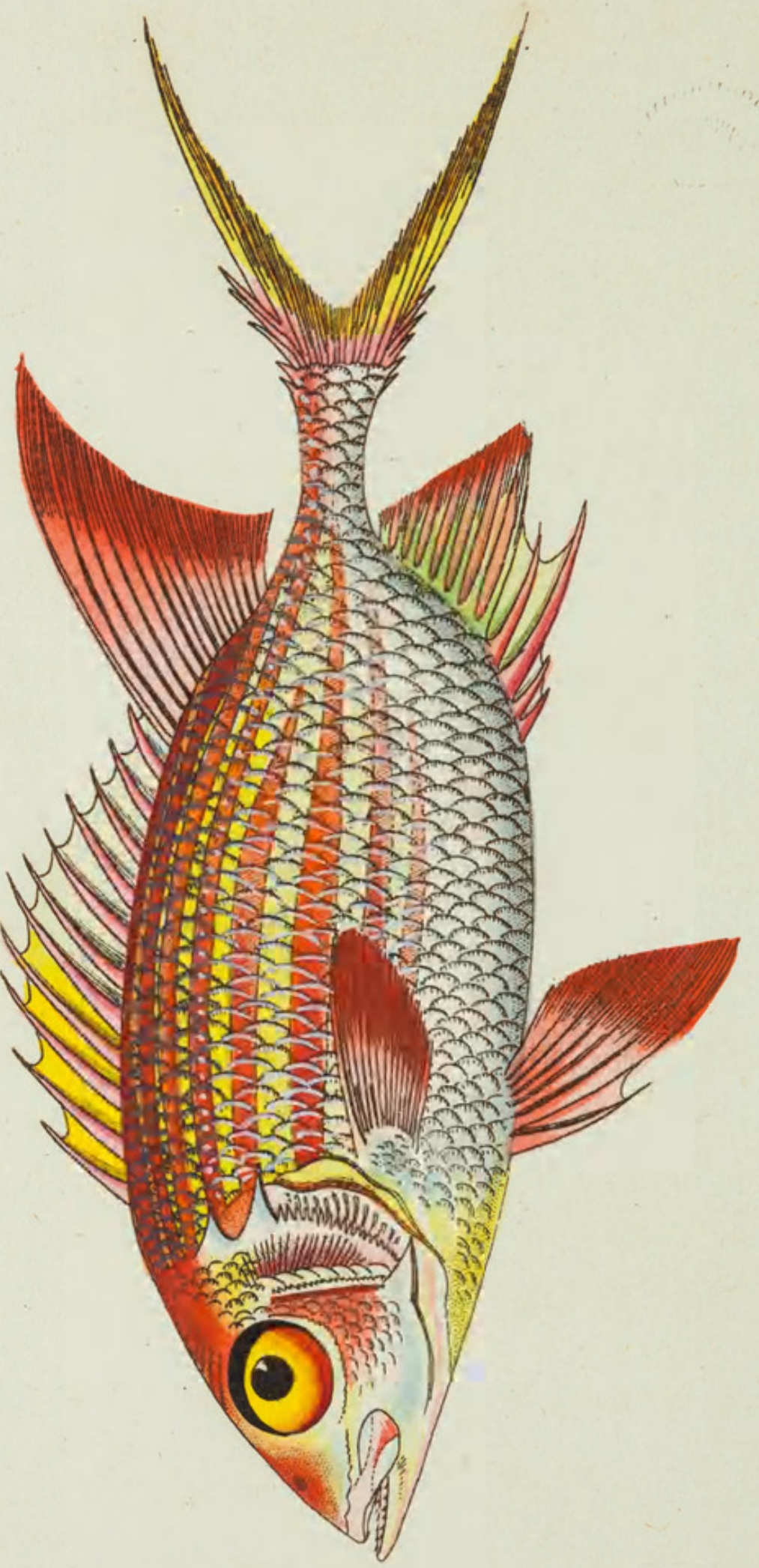




\section{THE \\ RED HOLOCENTRUS。}

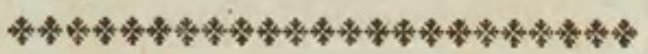

GENERIC CHARACTER.

Gill-Covers scaly, serrated, spiny.

SPECIFIC CHARACTER, EेC.

RED HOLOCENTRUS with longitudinal yellow stripes and forked tail.

The Sogo or RED HOLOCENTRUS.

The Squirrel.

Catesb. Carol. 2. pl. 3. f. 2 .

Der Sogo.

Bloch. ichth. 7. pl. 232.

The Holocentrus Sogo is a native of the Indian seas, and is of the size of a common perch. It is to the celebrated Plumier that we owe the archetypal figure of this fish, which has been engraved in the work of Dr. Bloch. 


\section{$2 \mathrm{BHL}$ Biodiversity Heritage Library}

Shaw, George. 1801. "The Red Holocentrus, Holocentrus sogo [PI. 522]." The Naturalist's Miscellany 13(CXLVII), https://doi.org/10.5962/p.310968.

View This Item Online: https://www.biodiversitylibrary.org/item/281546

DOI: https://doi.org/10.5962/p.310968

Permalink: https://www.biodiversitylibrary.org/partpdf/310968

\section{Holding Institution}

Museums Victoria

\section{Sponsored by}

Atlas of Living Australia

\section{Copyright \& Reuse}

Copyright Status: Public domain. The BHL considers that this work is no longer under copyright protection.

This document was created from content at the Biodiversity Heritage Library, the world's largest open access digital library for biodiversity literature and archives. Visit BHL at https://www.biodiversitylibrary.org. 